\title{
Evaluation of different parts of Berberis lyceum and their biological activities: a review
}

\author{
Sajjad Ahmed ${ }^{1}$, Muhammad Shuaib ${ }^{2 *}$, Kashif Ali $^{3}$, Sajjad Ali ${ }^{4}$ and Fida \\ Hussain ${ }^{5}$ \\ 1. Key Laboratory of Molecular Epigenetics, Ministry of Education, School of Life Sciences, Northeast Normal \\ University, Changchun, 130024, Jilin, PR-China \\ 2. School of Ecology and Environmental Science, Yunnan University, NO.2 North Cuihu Road, Kunming, Yunnan, \\ 650091, PR-China \\ 3. Department of Botany, Islamia College University Peshawar-Pakistan \\ 4. Department of Botany, Bacha Khan University Charsadda-Pakistan \\ 5. School of Resources, Environmental and Chemical Engineering Nanchang University, Nanchang Jiangxi-China \\ *Corresponding author's email: zeyadz44@yahoo.com \\ Citation \\ Sajjad Ahmed, Muhammad Shuaib, Kashif Ali, Sajjad Ali and Fida Hussain. Evaluation of different parts of \\ Berberis lyceum and their biological activities: a review. Pure and Applied Biology. Vol. 6, Issue 3, pp897-907. \\ http://dx.doi.org/10.19045/bspab.2017.60095
}

Received: 17/03/2017

Revised: 13/07/2017

Accepted: 17/07/2017

Online First: 21/07/2017

\section{Abstract}

Berberis lycium is a common medicinal plant which belongs to family Berberidaceae. It is native to Pakistan and India. It is used medicinally for diarrhea, internal wounds, jaundice, internal colic, piles, diabetes, backache, rheumatism, throat pain, scabies, pustules, gingivitis, sub blindness, remittent fever and eye disorder. The various parts of Berberis lycium such as roots, stem, leaves, and fruit contain bioactive compounds like carbohydrates, proteins, fats, vitamin $\mathrm{C}$, tannins, saponins, alkaloids, anthocyanins, berberine, berbamine, chinabine, baluchistanamine and sindamine. It contains various minerals i.e. sodium, phosphorus, copper, potassium, Iran, and zinc. The plant have shown many biological activities including anti-diabetic property, antimicrobial property, antihyperlipidemic property, hepatoprotective property, pesticidal property, antioxidant properties and wound healing properties. In light of current review there is a need of additional investigation and exploration regarding the medicinal value of this plant.

Keywords: Berberis lycium; Phytochemical; Biological activities; Medicinal uses

\section{Introduction}

Berberis lycium belongs to family Berberidaceae, [1] established this family as "Berberides" and is considered as one of the oldest angiosperms which possess a high number of discontinues genera [2]. This family is comprised of 17 genera and 650 species. The English name of Berberis lycium is barberry [3], while "Kashmal" is the word used for the fruit of this plant [4, 5], and roots are called as "Darhald" [6]. The plant is a native species of Nepal [3], however, the species has been reported throughout Himalayas Mountains, temperate and semi-temperate localities of Afghanistan, Bangladesh, India, and Pakistan [7]. In Pakistan grows in KPK, 
Baluchistan, Punjab and Azad Kashmir at an altitude of 900-2900 meters [8].

Berberis lycium is a spiny deciduous shrub with an average height of 2-4 meters. The plant bear lanceolate leaves which are alternately arranged on the stem [9]. The plant is self-fertile with hermaphrodite bright yellow colored flowers. The flowers are entomophilous, 11 to 16 in number and possess corymbs racemes inflorescence [10]. March to July mark the flowering season of this species. The color of the flowers changes from yellow to purple on ripening (that is fruits).

Berberis lycium produces an ovoid fruit which is up to 7 millimeter long and is known as Berries. The fruits start ripening from the 2nd week of May and remain to do so throughout June. Its fruit is usually used either cooked or raw and prepared into preservatives. The fruit is slightly acidic and juicy in nature. The plant possesses wide ecological amplitude and seeds can be grown in sandy, silty or loamy soils. The plant has a hard and branched root with a diameter ranging from 3 to $8 \mathrm{~cm}$. The root bark is thick which is fissured externally and smooth internally [11]. The cork is 5-10 cells thick, xylem with spiral, cambium, reticulate and pitted tracheae [12]. Examination of pollen morphology through scanning electron microscope revealed that the Pollen diameter in Berberis kunawurensis is around $38.71 \mu \mathrm{m}$ and exine thickness is about $2.25 \mu \mathrm{m}$ [13]. Honey bees also visit this plant for nectar [14].

B. lycium species have been declared vulnerable by the International Union for Conservation of Nature (IUCN) [15]. It is one of the endangered species of Pakistan [16]. B. lycium has been reported to contain important alkaloids like berberine [8, 1719], berbamine [20], Palmitine [18, 19], karakoramine, baluchistanamine, jhelumine, gilgitine, umbellatine [5] and chinabine [21]. The plant is recognized to have
Carbohydrates, Proteins, Lipids, and Vitamins [10], hydrolysable tannins, saponins and cardioactive glycosides [22]. Fruits are known to have moisture, phytic acid, hemicelluloses, $\beta$ carotein, vitamin A, cellulose and anthocyanins [10]. The plant is also recognized to have various minerals including zinc, copper, sulphur, sodium, calcium, iron [19], lead, magnesium, copper [23], potassium and phosphorus [10].

B. lycium is found to be effective against microorganisms. It is confirmed to have efficient antifungal and antibacterial activity [24]. The plant is also reported to be anticoccidial and immunostimulant [25], antimutagenic [26], hypoglycemic [22], antihyperlipidemic [27], pesticidal [28], hepatoprotective [29]. The plant is also proved efficient is healing wounds [30]. Moreover, the alkaloid berberine from this species is confirmed to be antipyretic [31], anti-inflammatory [32], anti hypercholesterolemia [33], antitumor [34], antidiarrheal [35] and antidiabetic [36].

\section{Taxonomy}

Berberis lyceum belongs to kingdom Plantae, Phylum: Tracheophyta, Class: Magnoliopsida, Order: Ranunculales, Family: Berberidaceae, Genus: Berberis, Species: lyceum, Scientific name: Berberis lycium.

\section{Phytochemical profile}

Berberis lycium is extensively studied for its phytochemical constituents. Various essential phytochemicals including alkaloids, saponins, minerals, and carbohydrates have been reported from this species. Modern technology such as atomic absorption spectrophotometer has made it easy to study mineral contents of plants. [19] Studied root and fruit of $B$. lycium for mineral contents by using atomic absorption spectrophotometer. His findings revealed that the root contains $0.2 \%$ zinc $(\mathrm{Zn})$ and $0.2 \%$ sulphur $(\mathrm{S})$, while the sulphur $(\mathrm{S})$ and zinc $(\mathrm{Zn})$ contents in fruit were $0.1 \%$ and 
$0.8 \%$, respectively. Similarly [23] examined roots and stem of B. lycium for lead $(\mathrm{Pb})$, copper $(\mathrm{Cu})$ and manganese $(\mathrm{Mn})$ through atomic absorption spectrophotometer. According to their results, the quantity of Lead $(\mathrm{Pb})$ found in stem and roots of the plant were $7.992 \pm 0.106$ and $4.360 \pm 0.176$ ppm, respectively. Result for Copper $(\mathrm{Cu})$ quantity in stem and roots were $5.031 \pm$ 0.176 and $4.360 \pm 0.176 \mathrm{ppm}$, individually. Manganese $(\mathrm{Mn})$ in the stem and root of the plant was $18.272 \pm 0.212$ and $15.500 \pm$ 0.212 ppm correspondingly.

In another study, Atomic absorption spectrophotometer was used by [10] to examine Phosphorous, Potassium, Iron, and Sodium, while by flame photometer Calcium quantity in the fruit of the said plant. The results showed the presence of Sodium $(14.5 \pm 0.11 \mathrm{mg} / 100 \mathrm{~g})$, Potassium $(161.42 \pm 0.41 \mathrm{mg} / 100 \mathrm{~g})$, Calcium (18.272 $\pm 0.212 \mathrm{mg} / 100 \mathrm{~g})$, Iron (2.61 \pm 0.06 $\mathrm{mg} / 100 \mathrm{~g})$ and Phosphorus (38.0 \pm 0.24 $\mathrm{mg} / 100 \mathrm{~g}$ ) in healthy amount. Leaves have also been reported to be plentiful in Iron (528.47 $\pm 0.02 \mu g g-1)$, Potassium (4077.00 $\pm 0.58 \mu \mathrm{gg}-1)$, Mn (136.12 $\pm 0.01 \mu \mathrm{gg}-1)$, Phosphorous (1315.00 $\pm 0.01 \mu g g-1), \mathrm{Cu}$ (53.41 $\pm 0.09 \mu \mathrm{gg}-1)$, Zinc $(37.71 \pm 0.02$ $\mu g g-1)$, Sodium (79.00 $\pm 0.01 \mu g g-1)$ and Calcium $(2389.00 \pm 0.04 \mu g g-1)$. It was shown by [37] that Copper, Zinc, and Sodium were concentrated in root, Potassium in shoot, while Phosphorous, Mn and Calcium in leaves shown in (Table 1).
B. lycium is also screened for moisture, proteins, sugars, fibers, vitamin and dry matter. According to [19], roots of B. lycium possess moisture $(20.5 \%)$, sugar $(3.5 \%)$, dry matter $(61.2 \%)$, fat $(2.6 \%)$, protein $(4.5 \%)$, Vitamin $\mathrm{C}(0.3 \%)$ and fiber $(2.5 \%)$ in the given percentages. Fruits comprise moisture (12.5\%), Vitamin C $(0.8 \%)$, dry matter $(62.5 \%)$, fat $(1.8 \%)$, protein $(2.5 \%)$, sugar $(4.5 \%)$ and fiber $(1.5 \%)$ in the given percentages. Roots showed the highest amount of fiber and fats while leaves showed highest amount of crude proteins [37] shown in (Table 2).

Phytochemical screening of water extract of B. lycium by [22] showed the presence of Cardiac glycosides, Saponins, Hydrolysable Tannins, and Alkaloids. Analysis of fruit revealed the presence of tannins $(8.9 \pm 0.15$ $\mathrm{mg} / 100 \mathrm{~g})$, Phytic acid $(2.5 \pm 0.04 \mathrm{mg} / 100$ g), $\beta$ - Carotene $(343.0 \pm 0.89 \mu \mathrm{g} / 100 \mathrm{~g})$, Phytate phosphorus $(0.78 \pm 0.06 \mathrm{mg} / 100 \mathrm{~g})$, Hemicellulose $(6.01 \pm 0.41 \%)$, Anthocyanin $(82.47 \pm 0.29 \mathrm{mg} / 100 \mathrm{ml}$ juice $)$, Vitamin A $(85.65 \pm 0.17 \mu \mathrm{g} / 100 \mathrm{~g})$ and Cellulose (7.94 $\pm 0.60 \%$ ) [10]. Essential alkaloids such as Berberine (Figure 1) and palmitine (Figure 1 ) in roots of $B$. lycium are found in a concentration of $4.5 \%$ and $3.1 \%$, respectively, while in fruits $2.9 \%$ Berberine is present [19], Berbamine [20], baluchistanamine, karakoramine, sindamine, gilgitine, jhelumine, punjabine, umbellatine [5] and Chinabine [21] are other alkaloids that have been recognized in $B$. lycium Shown in (Table 2).

Table 1. Minerals in different parts of Berberis lycium

\begin{tabular}{|l|l|l|l|}
\hline S. No & Minerals & Parts available & References \\
\hline 1 & Sulphur(S) and Zinc $(\mathrm{Zn})$ & Root, Fruit & {$[19]$} \\
\hline 2 & Copper(Cu) and manganese(Mn) & {$[23]$} \\
\hline 3 & $\begin{array}{l}\text { Phosphorous (P), Potassium (K), Iron (Fe) } \\
\text { and Sodium(Na) }\end{array}$ & Roots, Shoots, Leaves & {$[10]$} \\
\hline
\end{tabular}


Table 2. Bioactive compounds in different parts of Berberis lycium

\begin{tabular}{|l|l|l|l|}
\hline S. No & Phytochemical & Part available & References \\
\hline 1 & Carbohydrates & Roots & {$[\mathbf{1 9 , 1 0 ]}$} \\
\hline 2 & Fats & Roots & {$[\mathbf{1 9}]$} \\
\hline 3 & Proteins & Roots & {$[\mathbf{1 9 ]}$} \\
\hline 4 & Vitamins C, & Roots & {$[\mathbf{1 9}]$} \\
\hline 5 & Tannins & Fruit & {$[\mathbf{2 2}]$} \\
\hline 6 & Alkaloids & Fruit & {$[\mathbf{2 2}]$} \\
\hline 7 & Saponins & Fruit, leaves & {$[\mathbf{2 2}]$} \\
\hline 8 & Anthocyanin & Roots & {$[\mathbf{1 0}]$} \\
\hline 9 & Berberine & Roots & {$[\mathbf{1 9}]$} \\
\hline 10 & Berbamine & Roots, fruit & {$[\mathbf{2 0}]$} \\
\hline 11 & Chinabine & Fruit & {$[\mathbf{2 1}]$} \\
\hline 12 & Baluchistanamine & Fruit & {$[\mathbf{5}]$} \\
\hline 13 & Sindamine & Fruit & {$[\mathbf{5}]$} \\
\hline
\end{tabular}<smiles>COc1ccc2cc3[n+](cc2c1OC)CCC1CC2OCOC2CC31</smiles>

(a)<smiles>COc1cc2c(cc1OC)C1Cc3ccc(OC)c(OC)c3CC1CC2</smiles>

(b)<smiles>COc1cc(CC2(C)c3cc(O)c(O)cc3CCN2C)ccc1O</smiles>

(c)<smiles>[R]OC1C(O[R])C(O[R])C(O[R])C(O[R])C1O[R]</smiles>

(d)

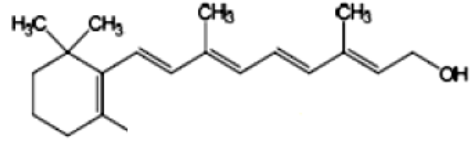

(e)

Figure 1. Structures of the major constituents of B. lycium. (a) Berberine [38] (b) Palmitine [38] (c) Berbamine [39] (d) Phytic acid [40] and (e) Vitamin A [41]

Folk medicines and Berberis lycium

A plant which possesses medicinal properties is known as a Medicinal plant. World Health Organization (WHO) defines medicinal plants as any plant whose organs contain medicinally active constituents with a therapeutic value or is used as a precursor to synthesize drugs (WHO). Usually, the extract of the plant is used to treat various ailments. The extract obtained is a kind of Traditional Medicine. Thus in developing countries, in order to maintain health, people use these medicinal plants and traditional medicines to cure their ailments and maintain good health [42]. Scientists are working to further explore the priceless 
properties of medicinal plants since a long time. Furthermore, more than $30 \%$ of modern medicines preparations are grounded on plants [43].

$B$. lycium Royle has also been used in folk medicine against diarrhea $[4,5,16,44-47]$, internal wounds $[16,46,48$,$] , jaundice [4$, $14,16,46$,$] , intestinal colic [16,45]$, piles $[4,10,16,44,47]$, diabetes $[15,48,49]$, ophthalmia $[4,26,44,45,50]$, backache [14] rheumatism [14, 45], manorrhagia [5], gingivitis [46], intermittent fever, sun blindness and remittent fever [45] Shown in (Table 3).

Plant is also febrifuge $[5,10,51,52]$ diuretic, expectorant [16] and diaphoretic [45]. Different organs of plants are used according to preparation. In the treatment of internal wounds, throat pain and dysentery, powder of the plant bark is used. Aqueous extract of root bark is used in the treatment of scabies, pustules, and diabetes whereas a paste made from root powder is used in bone fractures. A decoction of the plant roots is known as "Rasaunt" which is used to treat eyes infections. Furthermore, the sap of young vegetative shoot is also used to treat eye disorders [50]. Jaundice is traditionally treated by rhizome decoction [14]. So far, traditional medicines have provided many valuable clues in the expansion of modern medicines against various diseases. Nevertheless, rediscovery of old-fashioned medicine is needed in light of modern knowledge of medicines [53] Shown in (Table 3).

In traditional medication system, B. lycium has been widely used to treat diabetics. Recent pharmacological investigations revealed that this plant decrease hyperglycemia and the possible mechanism of this plant to have antidiabetic activity are attributed to its insulin-like mechanism. Moreover, the plant has been used traditionally to treat wounds, gingivitis, and rheumatism. One of the major alkaloids from this plant is called Berberine. Berberine is anti-inflammatory [53] shown in (Table 3).

Table 3. Medicinal uses of different parts of Berberis lycium

\begin{tabular}{|l|l|l|l|}
\hline S. No & Medicinal uses & Part uses & References \\
\hline 1 & Diarrhea & Roots & {$[4,5,16,44-47]$} \\
\hline 2 & Internal wounds & Roots & {$[16,45,48]$} \\
\hline 3 & Jaundice & Roots & {$[5,14,46]$} \\
\hline 4 & Intestinal colic & Roots, barks & {$[16,44]$} \\
\hline 5 & Piles & Roots & {$[5,16,18,44,47]$} \\
\hline 6 & Diabetes & Roots & {$[15,48,49]$} \\
\hline 7 & Ophthalmia & Root, leaves & {$[5,26,44,45,50]$} \\
\hline 8 & Backache & Roots and leaves & {$[14]$} \\
\hline 9 & Rheumatism & Roots & {$[45,14]$} \\
\hline 10 & Throat pain, Scabies, pustules & Roots & {$[48]$} \\
\hline 11 & Gingivitis & Roots & {$[46]$} \\
\hline 12 & Sun blindness, remittent fever & Roots, fruit & {$[45]$} \\
\hline 13 & Eye disorder & Roots & {$[50]$} \\
\hline 14 & Anti-inflammatory & Whole & {$[53]$} \\
\hline
\end{tabular}




\section{Pharmacological properties} Antidiabetic property of B. lycium

$B$. lycium is known to have antidiabetic property. [9] conducted an experiment to study the effect of $B$. lycium on alloxan induced diabetic rats. Crude powder and extracts of B. lycium were used in the study. The extracts used in the study were aqueous, methanolic, n-hexane, aqueous methanolic and chloroform. Results from his study revealed that the blood glucose level was declined by crude powder in both normal and diabetic rabbits. Aqueous extract caused maximum hypoglycemic activity for about 6 hours. While n-hexane, methanolic and aqueous methanolic extracts lowered blood glucose level for about 4 hours. The results obtained from chloroform extracts showed non-significant activity against diabetics. To further study the effect, water extract was compared insulin. Results revealed that water extract $(500 \mathrm{mg} / \mathrm{kg})$ with insulin $(2$ units) was comparable with many insulin units (6 units). Similarly, [19] evaluated the effect of aqueous and ethanolic extracts of root on normal and alloxanized rats. In the study, the reference drug was glibenclamide
(20 $\mathrm{mg} / \mathrm{kg})$. Blood glucose level was evaluated from serum by glucose oxidase method. Results revealed lowered hyperglycemia at 50 and $100 \mathrm{mg} / \mathrm{kg}$ dose after 3 to 5 hours of treatment. The dose of $100 \mathrm{mg} / \mathrm{kg}$ showed the more pronounced effect on the subjects. Serum glucose level was decreased in oral glucose tolerance test in a dose-dependent manner by the plant extracts. Insulin-like effect was observed in hypoglycemia which could be due to peripheral glucose consumption. Behavioral changes and acute toxicity were not observed in the experimental animals at the given doses. A comparative study of pure berberine and ethanolic root extract of $B$. lycium was performed on alloxan induced diabetics rats and normal rats. Same doses of berberine $(50 \mathrm{mg} / \mathrm{kg})$ and ethanolic root extract were provided to the rats. Surprisingly, plant extract in comparison with berberine showed the same efficiency in reducing blood glucose level. An efficient effect was also seen on serum lipid profile, body weight and glycosylated hemoglobin [19] Shown in (Table 4).

Table 4. Pharmacological and biological activities of Berberis lycium

\begin{tabular}{|l|l|l|}
\hline S.No & Biological activity & References \\
\hline 1 & Anti-diabetic property & {$[19,22]$} \\
\hline 2 & Antimicrobial property & {$[\mathbf{2 4 , 2 5 , 5 4 ]}$} \\
\hline 3 & Hepatoprotective property & {$[\mathbf{2 9 , 5 5 ]}$} \\
\hline 4 & Antihyperlipidemic property & {$[\mathbf{2 2 , 2 7}]$} \\
\hline 5 & Pesticidal property & {$[\mathbf{2 8}]$} \\
\hline 6 & Wound healing property & {$[\mathbf{3 0}]$} \\
\hline 7 & Antioxidant properties & {$[\mathbf{5 6 - 5 8}]$} \\
\hline
\end{tabular}

\section{Antimicrobial property of $B$. lycium}

Medicinal plants have the potential to kill bacteria and fungus pathogens. Antimicrobial activities of medicinal plants are due to the phytochemicals. B. lycium has a rich profile of phytochemicals, thus this plant is also tested against various pathogens. Microdilution method was used to study the antimicrobial activity of hydroalcoholic $(50 \%)$ extract of root and stem (air dried) of B. lycium by [24]. Enterobacter aerogenus, Klebsiella pneumonia, Bacillus subtilis, Pseudomonas aeruginosa, Micrococcus luteum, Escherichia coli, Bacillus cereus, Proteus mirabilis, Staphylococcus aureus, 
Streptococcus pneumonia and Salmonella typhimurium were the species against which the plant extract showed antimicrobial activity. Minimum inhibitory concentration (MIC) showed against each organism by root extract was $2.50,1.25,0.62,0.62,1.25$, $0.31,2.50,1.25,0.62,0.62$ and $2.5 \mu \mathrm{g} / \mathrm{ml}$, respectively. MIC showed by stem extract was $1.25,0.31,0.31,0.31,0.31,0.62,2.50$, $0.31,0.62,1.25$ and $0.62 \mu \mathrm{g} / \mathrm{ml}$, respectively. Hydroalcoholic extract of $B$. lycium has been proved to be effective against bacterial strains as compared to fungal strains [54].

The fungal strain of Aspergillus terreus was also inhibited by the stem and root extract at MIC 0.62 and $0.31 \mu \mathrm{g} / \mathrm{ml}$, respectively. Root extract also showed activity against Aspergillus flavus and Aspergillus spinulosus at MIC1.25 and $0.62 \mu \mathrm{g} / \mathrm{ml}$, respectively. $B$. lycium showed better immune performance against infectious bursal disease, newcastle disease, and infectious bronchitis. Coccidial oocysts/gram of feces showed a significant reduction in response to this plant [25]. The plant was also mixed in containers of drinking water along with other medicinal plants to reduce pathogens and kill germs Shown in (Table 4).

\section{Hepatoprotective property}

B. lycium is known to have hepatoprotective property. Methanolic extract and crude powder were used to study the hepatoprotective property of this plant in rabbits. Hepatotoxicity was induced by paraceutamol in the experimental organism. Results revealed that the elevated amount of serum glutamic oxaloacetic transaminase, serum glutamic pyruvic transaminase alkaline phosphatase enzymes were significantly reduced by the plant in treated rabbits [55]. B. lycium significantly reduced hepatotoxicity in hepatotoxic mice (Paraceutamol induced hepatotoxicity). $B$. lycium bark powder is also confirmed to have hepatoprotective activity [29] Shown in (Table 4).

\section{Antihyperlipidemic property}

B. lycium roots were used to study antihyperlipidemic property in male albino rabbits. From the results, it was concluded that oral use of crude powder (250 and 500 $\mathrm{mg} / \mathrm{kg}$ ) for four weeks significantly decreased triglyceride level, total cholesterol level and low-density lipids (LDLs) while high-density lipids (HDLs) were increased in rabbits. It was also observed that the weight of diabetic rabbits was highly stabilized by the provided doses [22].

[27] Studied the hypolipidemic effect of root bark of B. lycium in broilers. Result showed significant decrease in the triglyceride, LDL, and total cholesterol while a dose dependent significant increase in HDL Shown in (Table 4).

\section{Pesticidal property}

Through Soxhlet apparatus, Petroleum ether and aqueous methanol extracts of B. lycium root were prepared and further dried under vacuum. Two higher doses (5000 and 10000 ppm) were used to study the activity of plant extract against pests. At the dose of 5000 ppm, the mortality rate shown by petroleum ether extracts were $25 \%$ against Helicoverpa armigera Hub and $92 \%$ against Aphis craccivora Koch. On the other hand at the dose of $10000 \mathrm{ppm}$, the mortality rate was $26 \%$ against Tetranychus urticae Koch, 96\% against $A$. craccivora Koch and $28 \%$ against H. armigera Hub and Plutella xylostella L. Extract of Petroleum ether repressed $A$. craccivora Koch at $458.65 \mathrm{ppm}$ fatal amount at 50\% (LC50) after 24 hours engagement time and 57.79 ppm LC50 after 48 hours. The LC50 at 48-hour contact was almost similar with to a chemical insecticide called Dimethoate at $24 \mathrm{~h}$ contact. The mortality rate shown by aqueous methanolic extract at the dose of 5000 ppm was $26 \%$ against $A$. craccivora Koch. Extract also displayed $44 \%$ death rate against $H$. 
armigera Hub, $43 \%$ against T. urticae Koch, $41 \%$ against $P$. xylostella $L$. and $68 \%$ against $A$. craccivora Koch [28] Shown in (Table 4).

\section{Wound healing property}

Swiss Wister rats were used to study wound healing property of B. lycium 'root extract. The models of wound repair used in the study were excision, incision and dead wound space while methanolic and aqueous extracts were used. Epithelialization and breaking strength of wounds were increased by both extracts. Collagen deposition, fibroblasts, and macrophages were found in aqueous treated rats. In methanolic treated rats, a significant amount of collagen deposition but with low fibroblast and macrophage was detected. Similarly, hydroxyproline content of granulation tissue and dry weight was also increased. In nutshell, it was concluded that methanolic extract was more efficient than the aqueous extract [30] Shown in (Table 4).

\section{Antioxidant properties}

Reactive oxygen species (ROS) such as hydrogen peroxide, - $\mathrm{OH}$ (hydroxyl radical) and superoxide anion are well known for their potential of causing diseases like Inflammation, Cancer, Rheumatoid arthritis, Aging and Atherosclerosis [56]. However, the formation of ROS and related disorders in humans can be averted by Natural antioxidants [57]. The root extract of $B$. lycium is known for antioxidant properties and strong reduction potential. Root extract converts potassium ferricyanide $(\mathrm{Fe} 3+)$ to potassium ferrocyanide $(\mathrm{Fe} 2+)$, which then reacts with ferric chloride and form a ferric ferrous complex that has an absorption maximum at $700 \mathrm{~nm}$. This test is comparatively inexpensive and simple. Reducing power assay does not measure the 'Thiol group' comprising reagents [58] shown in (Table 4).

\section{Conclusion}

In the present review, various aspects of $B$. lycium have been discussed. B. lycium is a native species of Nepal but is also found throughout the Himalayas. It is a multipotential plant with many characteristics. The plant contains essential phytochemicals such as alkaloids, saponins, tannins, carbohydrates, phenols, glycosides, proteins and essential elements like zinc, copper, magnesium, potassium, sulfur, phosphorous, iron. Alkaloid berberine which has many pharmacological effects is also found in this plant. Berberine is anti-diarrheal but the exact mechanism of action is uncertain. Therefore, in vivo anti-diarrheal activities and in vitro spasmolytic activities of plant extracts are required to find the underlying mechanism. The plant extracts have been proved to possess pharmacological properties. The extracts are known to be antidiabetic, antimicrobial, antioxidants, pesticidal, antihyperlipidemic, hepatoprotective and wounded healers. However, the active constituents responsible for these pharmacological activities are unknown. Similarly, clinical data regarding the authenticity and efficiency of these pharmacological activities is very limited which pose a serious limitation to our knowledge and understanding. Thus more work is required to point out the underlying phytochemicals which are responsible for various activities of this plant. Also, a strong clinical data regarding these activities is also needed.

\section{Authors' contributions}

Plant selection \& idea: S Ahmed \& M Shuaib Analyzed the Data: K Ali \& S Ali, Contributed reagents/ materials/ tools: $\mathrm{M}$ Shuaib, K Ali, S Ali \& F Hussain, Wrote the paper: S Ahmed, M Shuaib \& F Hussain.

\section{References}

1. Jussieu AL (1789). de. Berberidaceae, nom. cons. Genera Plantarum 286. 
2. Bruckner C (2000). Clarification of the Carpel Number in Papaverales, Capparales, and Berberidaceae. Botanical Review 66: 155-307.

3. Anwar AK, Ashfaq M \& Nasveen MA (1979). Pharmacognostic studies of selected indigenous plants of Pakistan, (Peshawar, NWFP, Pakistan: Pakistan Forest Institute).

4. Usman GK, Saeed A \& Alam MT (1997). Indusyunic medicine, (Karachi, Pakistan: University of Karachi press) p.120.

5. Baquar SR (1989). Medicinal and Poisonous plants of Pakistan, (Karachi, Pakistan: Printas) p.55.

6. Nadkarni KM (1980). Indian Material Medica, (Bombay, India: Popular Parakshan Depot) pp.180-190.

7. Fluck H (1971). Medicinal Plants (New York, USA: W. Foul Sham and Co. Ltd) pp149-165.

8. Ali MN \& Khan AA (1978). Pharmacognostic studies of Berberis lycium Royle and its importance as a source of raw material for the manufacture of berberine in Pakistan. Pak J For p. 26.

9. Dhar Uppeandra, Kachroo P (1983).Alpine flora of Kashmir Himalaya 180.

10. Sood P, Modgil R \& Sood M (2010). Physico-chemical and nutritional evaluation of indigenous wild fruit Kasmal, Berberis lycium Royle. Indian J Nat Prod Res 1: 362-366.

11. Ahmad M, Alamgeer \& Sharif T (2009). A potential adjunct to insulin Berberis lyceum Royle. Diabet croatic 38(1): 1318.

12. Mahmood A, Ahmad M, Jabeen A, Zafar M \& Nadeem S (2005). Pharmacognostic Studies of Some Indigenous Medicinal Plants of Pakistan. Ethnobot. Leaflets 9:20.
13. Perveen A \& Qaiser M (2010). Pollen flora of Pakistan-Lxv. Berberidaceae. Pak J Bot 42(1):1

14. Zabihullah Q, Rashid A \& Akhtar N (2006). Ethnobotanical survey in kot Manzaray Baba valley Malakand agency, Pakistan. Pak J Plant Sci 12(2): 115-121.

15. Waseem M, Shah MA, Qureshi RA, Iqbal M, Afza R \& Yousaf S (2006). Ethnopharmacological Survey of Plants Used for the Treatment of Stomach, Diabetes, and Ophthalmic Diseases in Sudhan Gali, Kashmir, Pakistan. Acta Bot Yunn 28(5): 535.

16. Hamayun M, Khan SA, Sohn EY \& Injung L (2006). Folk medicinal knowledge and conservation status of some economically valued medicinal plants of District Swat Pakistan. Lyonia 11(2): 101-113.

17. Chandra P \& Purohit AN (1980). Berberine contents and alkaloid profile of Berberis species from different altitudes. Biochem. Sys Eco 8(4): 379380.

18. Gosh AK, Bhattacharyya FK \& Ghosh DK (1990). Leishmania donovani: A mastigote Inhibition and mode of action of berberine. Exp Para 60(3): 404-413.

19. Gulfraz M, Arshad M, Nayyer N, Kanwal N \& Nisar U (2004). Investigation for bioactive compounds of Berberis lyceum Royle and Justicia adhatoda L. Ethnobot. Leaflets 1: 51-62.

20. Khare CP (2004) Indian Herbal Remedies. In: Rational Western Therapy, Ayurvedic and Other Traditional Usage, Botany. (Springer) p.98.

21. Manske RHF (1998). The alkaloids: Chemistry and Pharmacology, (San Diego, California: Academic press, INC) p.287.98

22. Ahmed M, Alamgeer, Sharif T, Zabta CHM \& Akbar A (2009). Effect of 
Berberis lycium Royle on Lipid Profile in Alloxan Induced Diabetic Rabbits. Ethnobot Leaflets 13: 702-708.

23. Srivastava S, Vartika R, Srivatava M, Rawat AKS \& Shanta M (2006). Estimation of heavy metals in different Berberis species and its market samples. Env.Monit. Assess 116: 315-320.

24. Singh M, Srivastava S \& Rawat AKS (2007). Antimicrobial activities of Indian Berberis species. Fitoterap 78: 574-576.

25. Nidaullah H, Durrani FR, Ahmad S, Jan IU \& Gul, S (2010). Aqueous extract from different medicinal plants as anticoccidial, growth promotive and immunostimulant in broilers. ARPN $J$ Agric Biol Sci 5(1): 53-59.

26. Khan M, Giessrgl B, Vonach C, Madlener S, Prinz S, Herbaceck I, Hölzl C, Bauer S, Viola K, Mikulits W, Quereshi RA, Knasmüller S, Grusch M, Kopp B \& Krupitza G (2010). Berberine and a Berberis lycium extract inactivate Cdc25A and induce $\alpha$ tubulin acetylation that correlate with HL-60 cell cycle inhibition and apoptosis. Mut Res 683: 123-130.

27. Chand N, Durrani FR, Qureshi MS \& Durrani Z (2007). Role of Berberis lycium in reducing serum cholesterol in broilers. Asian-Australasian. J Ani Sci 20(4): 563-568.

28. Tewary DK, Bhardwaj A \& Shanker A (2005). Pesticidal activities in five medicinal plants collected from mid hills of western Himalayas. Indus Crop Prod 22: 241-247.

29. Khan MA, Jehanzeb, Shafiullah, Malik SA \& Shafi M (2008). Hepatoprotective effects of Berberis lycium, Galium aparine and Pistacia integerrima in carbon tetrachloride (CCL4) treated rats. J Post Grad Med Inst 22(2): 91-94.

30. Asif A, Kakub G, Mehmood S, Khunum R, \& Gulfraz M (2007). Wound Healing
Activity of Root Extracts of Berberis lyceum Royle in Rats. Phytother Res 21: 589-591.

31. Küpeli E, Koşar M, Yeşilda E, Başer KHC \& Başer C (2002). A comparative study on the anti inflammatory, antinociceptive and antipyretic effects of isoquinoline alkaloids from the roots of Turkish Berberis species. Life Sci 72: 645-657.

32. Kuo C, Chi C \& Liu T (2004). The antiinflammatory potential of berberine in vitro and in vivo. Can Lett 203: 127-137.

33. Doggrell SA (2005). Berberine-a novel approach to cholesterol lowering. Exp. Opi Inv Drug 14(5): 683-685.

34. Issat T, Jakóbisiak M \& Golab J (2006). Berberine, a natural cholesterol reducing product, exerts antitumor cytostatic/cytotoxic effects independently from the mevalonate pathway. Onco Rep 16: 1273- 1276.

35. Zhang MF \& Shen YQ (1989). Antidiarrheal and anti-inflammatory effects of berberine. Acta Pharmacol Sin 10(2): 174-176.

36. Steriti R (2010). Berberine for Diabetes Mellitus Type 2. Nat Med J 2(10): 5-6.

37. Shah H, Shad AA, Perveen S, Khattak S \& Khattak KF (2003). Physiochemical composition of wild medicinal plant Berberis lycium. Pak J App Sci 3(6): 370-375.

38. Singh A (2010). Physicochemical and physiological aspects. In: CRC Handbook of Free Radicals and Squadrito, G. L.; Pryor, W.A. Oxidative Chemistry of Nitric Oxide, Free. Radicals. Biol Med 25: 392-403. 1989.

39. Wen-Ying H, Cheng-Hung S \& ShueenJyi S (2006). Separation and Identification of the Constituents in Fangchi Radix of Different Origins. $J$ Food Drug Anal 14(4): 357-367.

40. Ali M, Shuja MN, Zahoor M \& Qadri I (2010). Phytic acid: How far have we 
come? Afr J Biotechnol 9(11): 15511554.

41. Huang ZR, Lin YK \& Fang JY (2009). Biological and Pharmacological Activities of Squalene and Related Compounds: Potential Uses in Cosmetic Dermatology. Molecules 14: 540-554.

42. Edward A (2001). Pathogenesis Justicia adhatoda (ed) New, Old and Forgotten remedies pp. 210-220.

43. Shinwari MI \& Khan MA (1998). Indigenous use of medicinal trees and shrubs of Margalla Hills National Park, Islamabad. Pak J Forest 48(1-4): 63-90.

44. Zaman MB \& Khan S (1970). Hundred Drug Plants of West Pakistan. (Peshawar, NWFP, Pakistan: Pakistan Forest Institute).

45. Kaur C \& Miani SB (2001). Fruits and vegetables health foods for new millennium. Indian Hort 45(4): 29-32.

46. Hamayun M, Khan A \& Khan MA (2005). Common Medicinal Folk Recipes of District Buner, NWFP, Pakistan. Ethnobot. Leaflets 1: 45.

47. Afzal S, Afzal N, Awan MR, Khan TS, Gilani A, Khanum R \& Tariq S (2009). Ethno-botanical studies from northern Pakistan. J Ayub Med Col Abbott 21(1): 52-57.

48. Ahmed E, Arshad M, Ahmad M, Saeed M \& Ishaque M (2004). Ethnopharmacological survey of some medicinally important plants of Galliyat areas of NWFP, Pakistan. Asian J Pl Sci 3: 410-415.

49. Tiwari JK, Dangwal LR, Rana CS, Tiwari P \& Ballabha R (2010). Indigenous uses of plant species in Nanda Devi Biosphere Reserve, Uttarakhand, India Repo Opin 2(2): 5861.

50. Uniyal SR, Singh KN, Jamwal P \& Lal B (2006). Traditional use of medicinal plants among the tribal communities of Chhota Bhangal, Western Himalaya. $J$ Ethnobiol Ethnomed 2: 14.

51. Shamsa F, Ahamadiani A \& Khosrokhavar R (1999). Antithistaminic and anticholinergic activity of Berbery fruit (Berberis vulgaris) in the guinea pig ileum. Ethnopharmacol 64: 161-166.

52. Mahmood A, Ahmad M, Jabeen A, Zafar M \& Nadeem S (2005). Pharmacognostic Studies of Some Indigenous Medicinal Plants of Pakistan. Ethnobot Leaflets 9: 20.

53. Aggarwal BB, Ichikawa H, Garodia $P$, Weerasinghe P, Sethi G, Bhatt ID, Pandey MK, Shishodia S \& Nair MG (2006). Traditional Ayurvedic medicine to modern medicine: identification of targets for suppression of inflammation and cancer. Expert Opin Ther Targets 10(1): 87-118.

54. Singh M, Srivastava S \& Rawat AKS (2009). Antimicrobial Studies of Stem of Different Berberis Species. Nat Prod Sci 15(2): 60-65.

55. Ahmad M, Alamgeer, Chaudhary MZ, Nadeem M, Sharif $\mathrm{T} \&$ Ahmad B (2008). Hepatoprotective effect of Berberis lycium (Royle) in hepatotoxic rabbits. Gomal. Uni J Res 24:24.

56. Singh M, Srivastava S \& Rawat AKS (2009). Antimicrobial Studies of Stem of Different Berberis Species. Nat Prod Sci 15(2): 60-65.

57. Shinwari ZK \& Gilani S (2003). Sustainable harvest of medicinal plants at Bulashbar Nullah, Astore (Northern Pakistan). J Ethnophormacol 84: 289-98.

58. Gupta R, Sharma M, Lakshamy R, Prabhakaran D \& Reddy KS (2009). Improved method of total antioxidant assay. Ind J Biochem Biophysic 46: 126129. 